\title{
STUDI KEAMANAN PERBANDINGAN BIOCHAR DAN TANAH DENGAN INDIKATOR CACING SERTA PENGARUHNYA TERHADAP PERKECAMBAHAN DAN PERTUMBUHAN KACANG HIJAU (Phaseolus radiatus)
}

\author{
Rima Anggraini' ${ }^{1}$, Suhirman ${ }^{2}$, dan Yahdi $^{3}$ \\ ${ }^{1}$ Jurusan tadris IPA Biologi FITK IAIN Mataram \\ ${ }^{2}$ Dosen Jurusan tadris IPA Biologi FITK IAIN Mataram \\ ${ }^{3}$ Dosen Jurusan tadris IPA Biologi FITK IAIN Mataram
}

\begin{abstract}
Abstrak
Penelitian ini bertujuan untuk mengetahui ada pengaruh perbandingan biochar dan tanah terhadap keamanan tanah berdasarkan indikator cacing, dan ada pengaruh tingkat keamanan perbandingan biochar dan tanah terhadap perkecambahan dan pertumbuhan kacang hijau (Phaseolus radiatus). Jenis penelitian yang digunakan adalah eksperimen dengan rancangan percobaan mengunakan rancangan acak kelompok (RAK). Data hasil penelitian dianalisis mengunakan Statistik Deskriptif, Chi Squer $\left(\mathrm{X}^{2}\right)$, Rang Spearman (Rs) untuk mengetahui Korelasi diantara tingkat keamanan cacing tanah dengan perkecambahan dan pertumbuhan serta biomassa tanaman kacang hijau selain itu untuk pertumbuhan dan biomassa kacang hijau di analisis juga dengan mengunakan ANOVA dan dilanjutkan dengan uji BNJ (Beda Nyata Jujur) pada taraf signifikansi 5\%. Hasil analisis pada Anova untuk pertumbuhan diperoleh nilai $\mathrm{F}_{\text {hitung }}$ perl. yakni 30,5 $>\mathrm{F}_{\text {tabel }} 5 \%=$ 3,33 , sedangkan biomassa untuk berat basah $\mathrm{F}_{\text {hitung }}$ perl. $=57,1>$ $\mathrm{F}_{\text {tabel }} 5 \%=3,33$, dan untuk berat kering $\mathrm{F}_{\text {hitung }}$ perl. $=56>\mathrm{F}_{\text {tabel }} 5 \%$ $=3,33$. Hasil dari penelitian menunjukkan bahwa adanya pengaruh pada variasi perbandingan persentase biochar terhadap pertumbuhan dan biomassa kacang hijau.
\end{abstract}

Kata Kunci: Biochar dan Tanah, Keamanan Cacing, Perkecambahan dan Pertumbuhan Tanaman Kacang Hijau (Phaseolus radiatus) 


\section{PENDAHULUAN}

Indonesia sebagai Negara tropis kaya akan sumber alam hayati dengan berbagai biomassa sehingga banyak di jumpai dan dianggap sebagai limbah, contohnya limbah pertanian, hutan, dan sebagainya. Pada proses pengolahan sumber daya alam hayati tersebut juga dihasilkan limbah biomassa seperti pada industri pengergajian kayu (sawmill) yang akan menghasilkan serbuk gergaji kayu, industri penggilingan padi akan menghasilkan sekam, dan industri minyak kelapa akan menghasilkan tempurung kelapa, selain itu pula semua industri pengolahan tersebut hampir tersebar pada semua daerah di Indonesia ini.

Proses penghancuran limbah secara alami berlangsung lambat, sehingga tumpukan limbah dapat menganggu lingkungan sekitarnya dan berdampak terhadap kesehatan manusia, padahal dengan melalui pendekatan teknologi, limbah pertanian dan perkebunan tersebut dapat diolah lebih lanjut sehingga dapat bernilai ekonomis tinggi. Contohnya biochar, karena dari setiap limbah industri yang ada dapat dijadikan sebagai biochar (arang hayati) dengan proses yang ramah lingkungan sehingga hal ini juga dapat mengurangi limbah industri tersebut.

Biochar merupakan bahan pembenah tanah yang terbuat dari residu tanaman, potongan kayu, dan pupuk kandang, biochar juga disebut arang hayati yang bersifat porous (berpori), dan dapat menambah kelembaban serta kesuburan tanah pertanian selain itu juga bisa bertahan ribuan tahun didalam tanah bila digunakan untuk pengurangan emisi $\mathrm{CO}_{2}$, sementara dalam jangka panjang biochar tidak menggangu keseimbangan karbonnitrogen, bahkan biochar mampu meningkatkan air dan nutrisi yang tersedia dalam tanah bagi tanaman.

Selain itu pula, di beberapa Negara telah ditetapkan suatu kebijakan untuk mengembangkan biochar dalam sekala industri guna meningkatkan simpanan karbon di dalam tanah. Jika dikaitkan dengan kepedulian terhadap pemanasan global yang disebabkan oleh emisi $\mathrm{CO}_{2}$ dan sumber gas rumah kaca lainya maka pemamfaatan biochar sebagai bahan pembenah tanah memiliki prospek yang cukup baik, oleh karena itu teknologi 
pemamfaatan (pengolahan) biochar merupakan salah satu solusi untuk mengurangi limbah industri dan pengaruh dari pemanasan global yang berasal dari lahan pertanian dan juga merupakan salah satu alternatif untuk mengolah limbah pertanian dan perkebunan.

Sumber bahan baku pembenah tanah alami yang mulai digunakan pada beberapa tahun terakhir adalah arang hayati (biochar) yang berasal dari residu atau limbah pertanian seperti kayu-kayuan, tempurung kelapa, sekam padi maupun limbah industri juga dapat digunakan seperti sisa gergaji kayu serta limbah kayu bangunan dan lain-lain. Efektivitas biochar dalam meningkatkan kualitas tanah sangat tergantung pada sifat fisik kimia dan fisik biochar yang ditentukan oleh jenis bahan baku (kayu lunak, kayu keras, sekam padi dan lain-lain) dan metode karbonisasi (tipe alat pembakaran, temperatur) dan bentuk biochar (padat, serbuk dan karbon aktif), sementara itu pengunaan bahan baku pembenah tanah dari limbah pertanian yang siap terdekomposisi merupakan salah satu alternatif yang dapat digunakan untuk mempercepat peningkatan kualitas sifat fisik tanah.

Di Indonesia mamfaat biochar sebagai soil conditioner terutama dalam praktek-praktek pengelolaan lahan hutan masih sangat jarang dilakukan, sementara potensi jumlah limbah pertanian dan hutan sedemikian berlimpah, antara lain dari hasil pembukaan lahan maupun aktivitas pemanenan yang meinggalkan limbah berupa daun, ranting termasuk pohon rusak. Berdasarkan data, potensi limbah biomassa berkayu hasil pembalakan hutan sekitar 29,70 juta $\mathrm{m}^{3} /$ tahun, limbah industri pengergajian kayu sekitar 1,40 juta $\mathrm{m}^{3} /$ tahun dan limbah perkebunan sekitar 27,32 juta $\mathrm{m}^{3} /$ tahun, melalui karbonisasi atau pirolisis setidaknya limbah tersebut dapat dikonversikan sebagai soil condisioner, dan disisi lain lahan kritis di Indonesia ini telah mencapai luasan sekitar 50 juta ha.

Tanah merupakan suatu sistem yang dinamis, yang tersusun dari empat komponen utama yaitu mineral, organik, air dan udara, diantara komponen penyusun tanah tersebut berbeda komposisinya dari setiap jenis tanah, kadar air dan perlakuan

228 BIOTA: Jurnal Tadris IPA Biologi FITK IAIN Mataram 
terhadap tanah. Selain itu tanah merupakan tempat dan sumber hidup bagi tanaman karena mampu menyediakan unsur hara bagi tanaman, tetapi unsur hara yang ada pada tanah tidak slalu dapat mencukupi kebutuhan hara tanaman dalam pertumbuhan dan perkembangannya. Hal ini akan mengakibat merosotnya produktivitas bahkan pada akhirnya tanah tidak mampu lagi menunjukkan kualitasnya yang lebih baik.

Adapun tingkat keamanan dari campuran biochar dengan tanah dapat dilihat dari suatu indikator cacing, karena cacing selain berperan melapukkan dan menghancurkan bahan-bahan organis di dalam tanah, juga berperan dalam menyuburkan tanah, sementara cacing tanah yang kadang-kadang sangat menjijikan itu merupakan penghuni tanah perkarangan disekitar rumah, tanah persawahan, tegalan, hutan dan tanah lainnnya. Cacing tanah atau Megascolecidae (Lumbricus terrestis) termasuk famili Annelida (cacing) bersegmen meliputi sekitar 6.000 spesies yang merupakan pelapuk dan penghancur bahan-bahan organis (sisa tanaman, dan binatang) yang bermamfaat dalam pembentukan tanah, namun banyak pula cacing yang bersifat parasit atau parasit fakultatif.

Banyaknya jumlah cacing yang tinggal atau hidup di dalam tanah menunjukkan tingkat keamanan tanah terhadap kenyamanan mikroorganisme lain atau dekomposer lain hidup di dalamnya. Dengan adanya dekomposer dalam tanah maka akan banyak penguraian bahan organik menjadi humus atau hara, pelapukan mineral, struktur, dan aerasi, sehingga tanah menjadi subur serta mampu meningkatkan produktivitas tanah.

Kacang hijau (Phaseolus radiatus) merupakan salah satu tanaman leguminoseae yang cukup penting di Indonesia. Posisinya menduduki tempat ketiga setelah kedelai dan kacang tanah. Sampai saat ini perhatian masyarakat terhadap kacang hijau masih kurang sehingga masih perlu dikembangkan sebagai tanaman pokok bagi masyarakat. Tanaman ini berbentuk semak yang tumbuh tegak dan merupakan tanaman semusim yang berumur pendek dengan tinggi 30-60 cm tergantung varietasnya. Sementara itu tanaman kacang hijau (Phaseolus radiatus) sangat memerlukan nutrisi dan zat-zat yang dibutuhkan oleh tanaman 
sehingga tanaman tersebut perlu mendapat perhatian yang lebih serius, khususnya dalam pertumbuhan tanaman kacang hijau tersebut. Oleh karena itu berdasarkan uraian latar belakang diatas maka peneliti tertarik untuk melakukan penelitian tentang Studi Keamanan Perbandingan Biochar Dan Tanah Dengan Indikator Cacing Serta Pengaruhnya Terhadap Perkecambahan Dan Pertumbuhan Kacang Hijau (Phaseolus radiatus).

\section{METODE PENELITIAN}

Desain penelitian merupakan suatu strategi untuk memperoleh data yang valid sesuai dengan karakteristik variabel dan tujuan penelitian serta penentuan yang matang tentang halhal yang akan dilakukan oleh peneliti. Desain penelitian merupakan landasan berpijak serta dapat pula dijadikan sebagai dasar penelitian oleh peneliti sendiri maupun orang lain terhadap kegiatan penelitian.

Dengan demikian, penelitian ini mengunakan desain penelitian eksperimen, yang meneliti tentang studi keamanan perbandingan biochar dan tanah dengan indikator cacing serta pengaruh terhadap perkecambahan dan pertumbuhan kacang hijau (Phaseolus radiatus). Sedangkan rancangan percobaan yang digunakan adalah Rancangan Acak Kelompok (RAK) dengan analisis statistik deskriptif.

\section{HASIL PENELITIAN}

Dari hasil penelitian yang dilakukan sesuai dengan prosedur kerja yang ada pada bab III tersebut berlangsung selama 2 bulan, selain itu parameter yang diamati dari hasil penelitian adalah tingkat keamanan cacing tanah (Lumbricus terristis) terhadap sampel campuran, jumlah perkecambahan pada masing-masing polybag, laju pertumbuhan tanaman kacang hijau (Phaseolus radiatus), serta biomassanya yakni berat basah (gram) dan berat kering (gram) tanaman kacang hijau (Phaseolus radiatus).

230 ВIOTA: Jurnal Tadris IPA Biologi FITK IAIN Mataram 


\section{Data Jumlah Cacing Tanah (Lumbricus terristis) Pada Setiap Sampel Campuran}

Penelitian ini di lakukan selama 2 hari (48 jam) untuk melihat tingkat keamanan cacing tanah (Lumbricus terristes) pada setiap sampel campuran. Data hasil pengamatan dapat disajikan pada Tabel 2 sebagai berikut :

Tabel 1

Data Jumlah Cacing Tanah (Lumbricus terristes) Pada Setiap Sampel Campuran

\begin{tabular}{|c|c|c|c|c|c|c|c|c|c|}
\hline \multirow{3}{*}{ No } & \multirow{3}{*}{$\begin{array}{c}\text { Perbanding } \\
\text { an (Biochar } \\
\text { \& tanah) }\end{array}$} & \multicolumn{6}{|c|}{ Kelompok (ulangan) } & \multirow{2}{*}{\multicolumn{2}{|c|}{ Total }} \\
\hline & & \multicolumn{2}{|c|}{1} & \multicolumn{2}{|c|}{2} & \multicolumn{2}{|c|}{3} & & \\
\hline & & $\mathrm{T}$ & $\mathrm{C}$ & $\mathrm{T}$ & $\mathrm{C}$ & $\mathrm{T}$ & $\mathrm{C}$ & $\mathrm{T}$ & $\mathrm{C}$ \\
\hline 1 & $1(\%): 99$ & 5 & 5 & 4 & 6 & 5 & 5 & 14 & 16 \\
\hline 2 & $2(\%): 98$ & 4 & 6 & 5 & 5 & 5 & 5 & 14 & 16 \\
\hline 3 & $4(\%): 96$ & 6 & 4 & 3 & 7 & 4 & 6 & 13 & 17 \\
\hline 4 & $8(\%): 92$ & 7 & 3 & 6 & 4 & 6 & 4 & 19 & 11 \\
\hline 5 & $16(\%): 84$ & 7 & 3 & 8 & 2 & 7 & 3 & 22 & 8 \\
\hline & Total & 29 & 21 & 26 & 24 & 27 & 23 & 82 & 68 \\
\hline
\end{tabular}

Keterangan:

$\mathrm{T}:$ tanah

C : campuran

Dari data tabel 1 di atas menunjukkan bahwa perlakuan III dengan perbandingan (4:96) menunjukkan hasil yang paling tinggi sedangkan hasil yang paling rendah pada perlakuan V dengan perbandingan biochar dan tanah adalah (16:84).

\section{Perkecambahan Kacang Hijau (Phaseolus radiatus )}

Pengamatan perkecambahan kacang hijau (Phaseolus radiatus) dilakukan setiap hari selama 1 minggu untuk mengetahui jumlah perkecambahan yang muncul pada 
masing-masing perlakuan yang diberikan. Adapun data hasil pengamatan perkecambahan dapat dilihat pada Tabel 4.2 sebagai berikut:

Tabel 2

Data Jumlah Perkecambahan Kacang Hijau Selama 1 Minggu

\begin{tabular}{|c|c|c|c|c|c|c|c|c|}
\hline \multirow{2}{*}{ No } & \multirow{2}{*}{ Perlakuan } & \multicolumn{7}{|c|}{ Perkecambahan Kacang Hijau } \\
\cline { 3 - 9 } & & $\begin{array}{c}\text { Hari } \\
\text { Ke-1 }\end{array}$ & $\begin{array}{c}\text { Hari } \\
\text { Ke-2 }\end{array}$ & $\begin{array}{c}\text { Hari } \\
\text { Ke -3 }\end{array}$ & $\begin{array}{c}\text { Hari } \\
\text { Ke-4 }\end{array}$ & $\begin{array}{c}\text { Hari } \\
\text { Ke -5 }\end{array}$ & $\begin{array}{c}\text { Hari } \\
\text { Ke -6 }\end{array}$ & $\begin{array}{c}\text { Hari } \\
\text { Ke -7 }\end{array}$ \\
\hline & 100 & - & 5 & 13 & 10 & 2 & - & - \\
\hline 1 & $1 \%: 99$ & - & 10 & 10 & 8 & 2 & - & - \\
\hline 2 & $1 \%: 98$ & - & 13 & 10 & 6 & 1 & - & - \\
\hline 3 & $2 \%: 96$ & - & 13 & 11 & 6 & 0 & - & - \\
\hline 4 & $4 \%: 92$ & - & 9 & 9 & 12 & 0 & - & - \\
\hline 5 & $8 \%: 84$ & - & 11 & 10 & 6 & 3 & - & - \\
\hline 6 & $16 \%: 93$ & & & & & & \\
\hline
\end{tabular}

Dari data tabel 2 di atas menunjukkan bahwa perkecambahan muncul paling cepat pada perlakuan IV dan V dengan masing-masing perbandingan (4\%:96) dan (8\%:92) sedangkan perkecambahan yang paling lambat menunjukkan pada perlakuan VI dengan perbandingan (16\%:84).

\section{Laju Pertumbuhan Tanaman Kacang Hijau (Phaseolus radiatus )}

a. Pertumbuhan Tinggi Batang (cm) Tanaman Kacang Hijau (Phaseolus radiatus)

Pada pengujian laju pertumbuhan kacang hijau (Phaseolus radiatus) ini, Pengukuran tinggi tanaman dilakukan satu kali seminggu selama enam minggu. Pengukuran ini dimulai dari minggu pertama setelah pengujian perkecambahan selesai dan menyisakan satu tanaman sebagai objek pengamatan pertumbuhan tinggi batang tanaman kacang hijau (Phaseolus radiatus ). Selain itu pengukuran tinggi batang dimulai dari permukaan tanah 
sampai ke ujung batang tanaman kacang hijau (Phaseolus radiatus ). Adapun data hasil pengukuran pertumbuhan tinggi batang tanaman kacang hijau (Phaseolus radiatus ) dapat dilihat pada Tabel 3 sebagai berikut:

Tabel 3

Data Hasil Pertumbuhan Tinggi Batang (cm) Tanaman Kacang Hijau (Phaseolus radiatus)

\begin{tabular}{|c|c|c|c|c|c|c|}
\hline \multirow{2}{*}{ No } & \multirow{2}{*}{$\begin{array}{c}(\%) \\
\text { Biochar } \\
\text { Dalam } \\
\text { Campuran }\end{array}$} & \multicolumn{3}{|c|}{ Kelompok (Ulangan) } & \multirow{2}{*}{ Total } & \multirow[b]{2}{*}{ Rerata } \\
\hline & & 1 & 2 & 3 & & \\
\hline 1 & 0 & 24,2 & 24,6 & 26 & 74,8 & 24,9 \\
\hline 2 & $1 \%$ & 27,6 & 27 & 28,2 & 82,8 & 27,6 \\
\hline 3 & $2 \%$ & 27,3 & 28,5 & 29,3 & 85,1 & 28,4 \\
\hline 4 & $4 \%$ & 29,5 & 31,6 & 32,4 & 93,5 & 31,2 \\
\hline 5 & $8 \%$ & 29,5 & 29,3 & 29,3 & 88,1 & 29,4 \\
\hline 6 & $16 \%$ & 27,2 & 27,3 & 27,7 & 82,2 & 27,4 \\
\hline & Total & 165,3 & 168,3 & 172,9 & 506,5 & \\
\hline
\end{tabular}

Dari Tabel 3 di atas menunjukkan bahwa rata-rata tinggi batang pada tanaman kacang hijau (Phaseolus radiatus) terdapat pada perlakuan IV (dengan perbandingan persentase biochar sebanyak 4\% : 96) setinggi $31,2 \mathrm{~cm}$. Sementara hasil yang terendah terdapat pada perlakuan I (tanpa pemberian biochar dan dijadikan sebagai kontrol) yakni setinggi $24,9 \mathrm{~cm}$.

\section{b. Biomassa (Berat Basah Dan Berat Kering) Tanaman Kacang Hijau (Phaseolus radiatus)}

Penimbangan berat basah dilakukan setelah pengukuran tinggi batang tanaman kacang hijau (Phaseolus radiatus) pada usia tanam enam minggu atau pada fase vegetatif. Sedangkan berat kering dihitung setelah 5 hari dikeringkan dan pengeringan dilakukan secara alami dengan 
menggunakan sinar matahari langsung. Adapun penimbangan berat basah dan berat kering dengan menggunakan timbangan Neraca Ohaus.

Data hasil penimbangan berat basah dan berat kering dapat disajikan pada Tabel 4 sebagai berikut:

Tabel 4

Data Hasil Penimbangan Biomassa Tanaman Kacang Hijau (Phaseolus radiatus)

\begin{tabular}{|c|c|c|c|c|c|}
\hline \multirow{2}{*}{ No } & \multirow{2}{*}{$\begin{array}{c}(\%) \\
\text { Biochar } \\
\text { Dalam }\end{array}$} & \multicolumn{4}{|c|}{$\begin{array}{c}\text { Biomassa Tanaman } \\
\text { Kacang Hijau }\end{array}$} \\
\cline { 3 - 6 } & \begin{tabular}{c} 
Bampuran \\
\cline { 3 - 6 }
\end{tabular} & Berat basah (gram) & Berat kering (gram) \\
\hline 1 & 0 & 46,4 & 15,5 & 1,6 & 0,5 \\
\hline 2 & $1 \%$ & 56,1 & 18,7 & 7,9 & 2,6 \\
\hline 3 & $2 \%$ & 64,3 & 21,4 & 9,4 & 3,1 \\
\hline 4 & $4 \%$ & 64,6 & 21,5 & 9,2 & 3,1 \\
\hline 5 & $8 \%$ & 63,6 & 21,2 & 8,3 & 2,8 \\
\hline 6 & $16 \%$ & 59,8 & 19,9 & 6,8 & 2,3 \\
\hline & Total & $\mathbf{3 5 4 , 8}$ & $\mathbf{1 1 8 , 2}$ & $\mathbf{4 3 , 2}$ & $\mathbf{1 4 , 4}$ \\
\hline
\end{tabular}

Pada tabel 4 di atas menunjukkan bahwa rata-rata berat basah pada tanaman kacang hijau (Phaseolus radiatus) yang tertinggi adalah pada perlakuan IV dengan berat 21,5 gram sedangkan hasil penimbangan yang terendah pada perlakaun I dengan berat 15,5 gram. Selain itu juga biomassa untuk berat kering yang tertinggi terdapat pada perlakuan III dan IV yaitu dengan berat 3,1 gram, sementara yang terendah yaitu pada perlakuan I dengan berat 0,5 gram. 


\section{PEMBAHASAN}

\section{Tingkat Keamanan Cacing tanah (Lumbricus terristis) Terhadap Sampel Campuran}

Dari hasil analisis data di atas bahwa pada perlakuan III menunjukkan kategori cukup (C) sedangkan pada perlakuan V menunjukkan kategori sangat kurang (SK). Dengan demikian penambahan biochar dengan variasi perbandingan pada perlakuan tersebut dapat memberikan pengaruh terhadap keamanan cacing pada suatu media.

Dilihat dari perlakuan III dengan perbandingan biochar $4 \%$, respon cacing tanah (Lumbricus terristis) terhadap sampel campuran bisa dikatakan baik, sebaliknya pada perlakuan $\mathrm{V}$ dengan perbandingan biochar 16\%, respon cacing tanah (Lumbricus terristis) terhadap sampel campuran kurang baik. Hal tersebut diduga karena perbandingan biochar yang 4\% lebih cepat mengalami keseimbangan dengan tanah sehingga cacing tanah lebih aman pada kondisi 4\%, sementara pada perbandingan biochar 16\% yang lebih banyak dari perlakuan lainnya maka membutuhkan waktu yang lebih lama untuk mencapai keseimbangan dengan tanah sehingga biota tanah aman pada kondisi perbandingan biochar 16\%, terutama pada cacing tanah (Lumbricus terristis) yang dijadikan sebagai indikator kesuburan tanah.

Cacing tanah (Lumbricus terristis) merupakan salah satu dari makrofauna tanah yang hidup di tanah-tanah yang lembab serta berperan penting sebagai peyelaras dan keberlangsungan ekosistem yang sehat, baik itu biota tanah lainnya maupun bagi hewan dan manusia.

Cacing tanah (Lumbricus terristis) selain berperan sebagai penyubur tanah juga memiliki peranan sebagai dekomposer bahan organik yang akan di ubah menjadi hara dan dengan adanya aktivitas cacing didalam tanah ini dapat memperbaiki sifat-sifat fisik tanah seperti ketersediaan hara, dekomposisi bahan organik, pelapukan mineral, struktur dan aerasi sehingga mampu meningkatkan produktivitas tanah. 
Reaksi tanah menunjukkan sifat kemasaman atau alkalinitas tanah yang dinyatakan dengan nilai $\mathrm{pH}$. Nilai $\mathrm{pH}$ menunjukkan banyaknya konsentrasi ion $\mathrm{H}^{+}$di dalam tanah. Makin tinggi kadar ion $\mathrm{H}^{+}$di dalam tanah maka semakin masam tanah tersebut. Adapun habitat cacing tanah pada prinsipnya dapat ditemukan pada tanah lahan kering masam sampai pada alkali (basa) yang memiliki kecukupan air. Sementara itu kemasaman tanah sangat mempengaruhi populasi dan aktivitas cacing sehingga menjadi faktor pembatas penyebaran dan spesiesnya. Umumnya cacing tanah tumbuh baik pada pH sekitar 7,0 namun Spesies Lumbricus terristis dan A. caliginose dijumpai pada $\mathrm{pH}$ 5,2-5,4. Penambahan char pada tanah dapat menurunkan keasaman tanah karena char yang berupa arang karbon bersifat basa.

Selain itu juga didukung dengan nilai $\mathrm{pH}$ yang ada pada biochar sesuai dengan penelitian sebelumnya mengatakan bahwa nilai $\mathrm{pH}$ biochar berada pada kisaran $\mathrm{pH}$ 5-8 yang hasil penelitiannya menunjukkan bahwa aplikasi dalam pemberian biochar pada tanah berpengaruh terhadap peningkatan $\mathrm{pH}$ tanah dan penurunan konsentrasi $\mathrm{Al}^{3+}$ dan $\mathrm{H}^{+}$. Sehingga peningkatan $\mathrm{pH}$ ini menyebabkan unsur hara menjadi lebih tersedia.

Makrofauna tanah membutuhkan ketersediaan unsur hara dan mineral yang cukup. Unsur hara yang ada dapat memberikan keamanan atau kenyamanan bagi biota tanah sehingga menjamin kesuburan tanah bagi pertumbuhan tanaman. Apalagi dengan adanya biochar ini dapat menjaga kesimbangan nutrisi yang ada pada tanah karena biochar selain menjaga juga dapat mengikat $\mathrm{CO}_{2}$ dan Nitrogen $(\mathrm{N})$ dalam waktu yang lebih lama. Serta memperbaiki sifat fisik, kimia dan biologi tanah.

\section{Perkecambahan Kacang Hijau (Phaseolus radiatus)}

Hasil analisis statistik deskriptif untuk perkecambahan kacang hijau (Phaseolus raditus) menunjukkan bahwa hasil persentase perkecambahan yang paling serentak muncul

236 BIOTA: Jurnal Tadris IPA Biologi FITK IAIN Mataram 
dipermukaan tanah sejak pada hari ke-2, sampai hari ke-5. Sementara yang paling cepat perkecambahannya yaitu pada perlakuan IV dan $V$ sedangkan yang lambat perkecambahannya terdapat pada perlakuan VI.

Perkecambahan merupakan tumbuhnya embrio (bakal) yang terdapat dalam sebutir biji. Embrio tersebut akan tumbuh menjadi tumbuhan kecil yang lambat laun akan tumbuh makin besar menjadi tumbuhan dewasa yang lengkap. Adapun perkecambahan itu terjadi karena pertumbuhan radikula (calon akar) dan pertumbuhan plumula (calon batang).

Berdasarkan hasil analisa untuk mengetahui ada atau tidaknya korelasi tingkat keamanan cacing tanah (Lumbricus terristis) pada sampel campuran dengan tingkat perkecambahan kacang hijau (Phaseolus radiatus) dapat disimpulkan bahwa tidak ada korelasi antara tingkat keamanan dengan tingkat perkecambahan kacang hijau (Phaseolus radiatus) selama 1 minggu pengamatan. Hal ini diduga karena kurangnya keseimbangan antara biochar dengan unsur hara yang ada pada tanah sehingga menyebabkan tidak adanya korelasi diantara keduannya.

Kacang hijau merupakan jenis tanaman yang membutuhkan nutrisi yang cukup tinggi terutama unsurunsur hara yang ensensial dan fungsinya juga tidak dapat digantikan oleh unsur lain, dan apabila hara tidak terdapat dalam jumlah yang cukup di dalam tanah, maka tanaman tidak dapat tumbuh dengan normal begitu pula pada fase perkecambahan.

3. Pertumbuhan Tanaman Kacang Hijau (Phaseolus radiatus) a. Pertumbuhan Tinggi Batang Tanaman Kacang Hijau (Phaseolus radiatus)

Hasil analisis data menunjukkan bahwa tingkat keamanan cacing tanah pada sampel campuran dengan pertumbuhan tinggi batang tanaman kacang hijau menunjukkan tidak ada korelasi antara keduannya. Sementara dari hasil Anova menunjukkan bahwa hasilnya 
signifikan artinya ada pengaruh perlakuan yang diberikan terhadap pertumbuhan tinggi batang tanaman kacang hijau (Phaseolus radiatus).

Tanaman secara umum sangat membutuhkan unsurunsur hara untuk melangsungkan pertumbuhannya adapun unsur hara yang dibutuhkan yaitu Karbon (C), Hidrogen $(\mathrm{H})$, Oksigen $(\mathrm{O})$, Fosfor $(\mathrm{P})$, Nitrogen $(\mathrm{N})$, Potasium $(\mathrm{K})$, Kalsium (Ca), Magnesium (Mg), Sulfur (S), Klor (Cl), Boron (B), Tembaga (Cu), Mangan (Mn), Besi (Fe), Seng (Zn), dan Molibdenum (Mo). Selain itu unsur hara N, P, dan K merupakan unsur hara utama yang diperlukan dalam jumlah banyak dan unsur hara mikro diperlukan dalam jumlah sedikit seperti $\mathrm{Fe}, \mathrm{Mn}, \mathrm{Zn}, \mathrm{Cu}, \mathrm{Bo}, \mathrm{Co}$, Mo, Na, Cl, dan Si. Sementara unsur hara yang sudah dimiliki oleh tanah itu sendiri adalah Nitrogen (N), Fosfor (P), Kalium (K), Kalsium $(\mathrm{Ca})$, Magnesium $(\mathrm{Mg})$, Belerang $(\mathrm{S})$, serta unsur-unsur hara mikro lainnya.

Penggunaan biochar dengan perbandingan 4\% sangat baik untuk pertumbuhan tinggi batang tanaman kacang hijau (Phaseolus radiatus), dengan perbandingan tersebut kebutuhan akan unsur hara esensial seperti Nitrogen maupun Posfor yang ada pada tanah dapat dijaga oleh biochar karena biochar selain berfungsi sebagai soil conditioner (pelembab tanah) juga dapat meretensi hara dan bertindak sebagai sumber hara atau pupuk guna menjaga keseimbangan nutrisi yang akan diserap oleh tanaman untuk pertumbuhan tinggi batang tanaman kacang hijau terutama pada fase vegetatif bila dibandingkan dengan perlakuan lainnya.

Unsur hara seperti Nitrogen berperan dalam pembentukan organ vegetatif tanaman seperti daun, batang dan akar. Kegunaan unsur nitrogen bagi tanaman adalah untuk meningkatkan pertumbuhan tanaman, meningkatkan kadar protein (asam amino) dalam tubuh tanaman dan meningkatkan kualitas tanaman penghasil daun. Selain itu Nitrogen juga terkandung dalam klorofil, hormon sitokinin, dan auksin. 
Jika ketersediaan unsur hara ensensial kurang dari jumlah yang dibutuhkan oleh tanaman, maka tanaman akan terganggu metabolismenya baik secara visual dapat terlihat dari penyimpangan pada fase pertumbuhannya. Adapun gejala tanaman pada saat terjadi kekurangan unsur hara ini dapat berupa pertumbuhan akar, batang, atau daun yang terhambat (kerdil) dan klorosis pada berbagai organ tanaman lainnya.

\section{b. Biomassa (Berat Basah dan Berat Kering)Tanaman Kacang Hijau Kacang Hijau (Phaseolus radiatus)}

Hasil analisis data berat basah dengan melihat korelasi pada tingkat keamanan cacing tanah (Lumbricus terristis) pada sampel campuran dengan nilai berat basah tersebut menunjukkan tidak ada korelasi diantara kedua variabel. Sementara untuk hasil analisis untuk melihat pengaruh dari perbandingan persentasenya dapat dianalisis dengan mengunakan Analisis Of Varian (Anova) yakni hasil yang diproleh menunjukkan bahwa hasilnya signifikan artinya ada pengaruh yang diberikan perlakuan terhadap hasil berat basah tersebut.

Tumbuhan banyak mengandung air didalam selselnya. Hal ini yang menyebabkan suhu tumbuhan relatif stabil walaupun menerima atau kehilangan energi. Berat basah tanaman kacang hijau (Phaseolus radiatus) lebih banyak mengandung air karena air merupakan salah satu komponen utama dalam keberlangsungan hidup tanaman, air yang terkandung dalam tanaman sekitar $70 \%$ sampai $90 \%$. Dengan adanya air proses metabolisme maupun secara reaksi biokimia ini akan memberikan hasil yang lebih baik pada biomassa tanaman kacang hijau (Phaseolus radiatus) terutama pada berat basah tanaman kacang hijau (Phaseolus radiatus).

Biochar juga mampu mengikat air yang ada pada tanah sehingga tanaman tidak mengalami dehedrasi terhadap suplai air. Selain itu juga keadaan tanah yang 
cukup lembab yang menunjukkan jumlah air banyak yang ditahan oleh tanah untuk diserap oleh akar-akar tanaman.

Jika tanaman berada dalam kondisi kekurangan air sebagai akibat kurangnya hujan maupun irigasi, maka proses pembentukan dan perkembangan organ tanaman akan sangat berpengaruh seperti pada daun, akar, dan batang, hal tersebut berhubungan dengan proses pematangan sel tanaman untuk menuju ke pertumbuhan yang dewasa. Sel tanaman akan membesar seiring dengan menebalnya dinding sel dan terbentuknya selulosa pada tanaman. Pengaruh lainnya terkait dengan ketersediaan air bagi tanaman, berupa penyerapan hara dari tanah bagi tanaman.

Hara yang berada di dalam tanah diangkut melalui air yang terserap oleh tanaman melalui proses difusi osmosis yang terjadi. Semakin baik hara yang terserap oleh tanaman, maka ketersediaan bahan dasar bagi proses fotosintesis akan semakin baik pula. Proses fotosintesis yang berlangsung dengan baik, akan memacu penimbunan karbohidrat dan protein pada tanaman kacang hijau.

Adapun hasil analisis berat kering tanaman kacang hijau (Phaseolus radiatus) yang hasilnya tidak jauh beda dengan hasil analisis dari berat basah di atas yang menunjukkan bahwa hasil dari analisis menggunakan Analisis of Varian yaitu memiliki pengaruh terhadap perbandingan persentase biochar dengan berat kering tanaman kacang hijau (Phaseolus radiatus). Hal ini terjadi karena proses pengeringan yang dilakukan untuk mengetahui jumlah komposisi air yang ada pada tanaman kacang hijau (Phaseolus radiatus). Pengeringan ini dilakukan secara alami dengan mengunakan sinar matahari langsung supaya berkurangnya komposisi air yang terkandung pada batang tanaman kacang hijau (Phaseolus radiatus) yaitu Hidrogen (H). 


\section{PENUTUP}

\section{Kesimpulan}

Berdasarkan hasil penelitian dan pembahasan, dapat diambil kesimpulan sebagai berikut:

1. Berdasarkan hasil pengujian dengan mengunakan cacing tanah sebagai indikator, terdapat pengaruh variasi perbandingan biochar dan tanah terhadap tingkat keamanan sampel campuran.

2. Berdasarkan hasil pengujian, tidak ada korelasi tingkat keamanan perbandingan biochar dan tanah terhadap perkecambahan kacang hijau (Phaseolus radiatus).

3. Berdasarkan hasil pengujian, tidak ada korelasi tingkat keamanan perbandingan biochar dan tanah terhadap pertumbuhan kacang hijau (Phaseolus radiatus). Akan tetapi dengan menggunakan Analisis of Varian menunjukkan adanya pengaruh yang signifikan dari variasi perbandingan persentase biochar terhadap pertumbuhan kacang hijau (Phaseolus radiatus). Dan sama halnya dengan biomassa tanaman kacang hijau yakni berat basah dan berat kering menunjukkan adanya pengaruh yang signifikan pada variasi perbandingan persentase biochar terhadap berat basah dan berat kering tanaman kacang hijau (Phaseolus radiatus)

\section{Saran}

1. Dari hasil penelitian ini, penulis menyarankan kepada masyarakat khususnya yang terjun pada bidang pertanian untuk menggunakan Biochar sebagai bahan pembenah tanah selain itu juga bisa sebagai pengganti pupuk karena dapat mengikat nutrisi yang ada pada tanah.

2. Perlu dilakukan penelitian lebih lanjut dengan menggunakan Biochar untuk melihat kesuburan tanaman kacang hijau (Phaseolus radiatus) atau untuk tanaman yang lainya.

3. Dalam penyusunan skripsi ini, penulis menyadari referensi yang membahas tentang judul ini masih sangat kurang sehingga penulis lebih banyak mengutip dari jurnal maupun skripsi peneliti sebelumnya, dan penulis menyarankan kepada semua pihak yang melakukan penelitian yang berkaitan 
dengan judul ini supaya hasil penelitiannya dicetak dalam bentuk buku, jurnal atau majalah dan lain-lain. Sehingga lebih bermanfaat bagi kita semua, serta dimanfaatkan dengan sebaik-baiknya.

4. Semoga hasil penelitian ini bermanfaat bagi kita semua dan menjadi Fokus kajian Mata Kuliah Biologi dari mahasiswa/i Pendidikan Biologi dan Dosen yang akan menjadi pembimbing dalam skripsi selanjutnya.

\section{DAFTAR PUSTAKA}

Almuth Ernsting and Rachel Smolker. Biochar For Clamate Change Mitigation Fact Or Fiction. 2009.

Andrianto dan Tohana Taufiq. Budi Daya Dan Analisis Usaha Tani Kedelai, Kacang Hijau, Kacang Panjang. Yogyakarta: Absolut, 2004.

Astawan made. Sehat Dengan Hidangan Kacang Dan Biji-Bijian. Jakarta: Penebar Swadaya, 2009.

Benyamin Lakitan. Dasar-Dasar Fisiologi Tumbuhan, Jakarta: PT RajaGrafindo Persada, 2008.

Chairani. Teknik Budidaya Tanaman. Jakarta : Sumber Bahagia Concern, 2008.

Em Zul Fajri \& Ratu Aprilia Senja. Kamus Lengkap Bahasa Indonesia. Jakarta : Difa Publisher, 2008.

Harris Herman Siringoringo Dan Khairil Anwar Siregar. Pengaruh Aplikasi Arang Terhadap Pertumbuhan Awal Mycelia Motana Blume Dan Perubahan Sifat Kesuburan Tanah Pada Tipe Tanah Latosol. Pusat Litbang Konsevasi Dan Rehabilitasi, 2011.

H, Darwis. Dasar-dasar Ilmu Pertanian dalam Al-Qur'an. Bogor : IPB Press, 2004.

http//www. Kendhil x Template, Blogspot. Com. Skripsi. /200902. /Kacang-Hijau. html-54k. Diakses tanggal 22 juli 2013 Pukul 10.23 Wita.

242 BIOTA: Jurnal Tadris IPA Biologi FITK IAIN Mataram 
Iskandar. Metodologi Penelitian Pendidikan dan Sosial, Jakarta: Pustaka Pelajar, 2008.

Kartasapoetra. Teknologi Konservasi Tanah Dan Air. Jakarta : Rineka Cipta, 2005.

Kemas Ali Hanafiah. Rancangan Percobaan Teori dan Aplikasi. Jakarta: Raja Grafindo Persada, 2005.

Kemas Ali Hanifah, dkk. Biologi Tanah (Ekologi \& Makrobiologi Tanah). Jakarta: PT RajaGrafindo Persada, 2007.

Kemas Ali Hanifah. Dasar-Dasar Ilmu Tanah. Jakarta : PT RajaGrafindo Persada, 2007.

Kheruman \& Khaerul Amri. Mengeruk Untung Dari Bertenak Cacing. Jakarta: Agromedia Pustaka, 2009.

Kusriningrum. Perancangan Percobaan. Surabaya: Airlangga Universitas Press, 2010.

Laksmita Prima Santi Dan Didik Hadjar Goenadi. Pemamfaatan Biochar Sebagai Pembawa Mikroba Untuk Pemantap Agrerat Tanah Ultisol Dari Taman Bogo-Lampung. Menara Perkebunan, 2010.

M. Ferizal. Arang Hayati (Biochar) Sebagai Bahan Pembenah Tanah. BPTP Nangroe Aceh Darussalam: Badan Litbang Pertanian, 2011.

Mahmud yunus. Tafsir Qur'an Karim. Malaysia : Klang Book Centre. 1997.

Margono. Metodelogi Penelitian Pendidikan, Jakarta: PT Rineka Cipta, 2004.

Margono. Metode Penelitian Pendidikan. Jakarta: Rineka Cipta, 2010.

Mul Mulyadi Sutedjo, dkk. Pengantar Ilmu Tanah (Terbentuknya Tanah Dan Tanah Pertanian). Jakarta: Rineka Cipta, 2005.

Mul Mulyadi Sutedjo. Pupuk Dan Cara Pemupukan. Jakarta :Rineka Cipta, 2008.

N.L. Nurida, dkk. Efikasi Formula Pembenah Tanah Biochar Dalam Berbagai Bentuk (Serbuk,Granula Dan Pelet) Dalam Meningkatkan Kualitas Lahan Kering Masam Terdegradasi. Balai Penelitian Tanah, 2008.

N.L. Nurida, dkk. Kualitas Limbah Pertanian Sebagai Bahan Baku Pembenah Tanah Berupa Biochar Untuk Rehabilitas Lahan. Balai Penelitian Tanah, 2008. 
Novizan. Petunjuk Pemupukan Yang Efektif, Jakarta: PT Agro Media Pustaka, 2005.

Poerwowidodo mas'ud. Telaah Kesuburan Tanah. Bandung : Angkasa, 1993.

Purwono Dan Heni Purnamawati, Budidaya 8 Jenis Tanaman Pangan Unggul. Jakarta : Penebar Swadaya, 2011.

Redaksi Agromedia. Petunjuk Pemupukan. Jakarta: Agromedia Pusaka, 2007.

Saifuddin sarief. Kesuburan dan Pemupukan Tanah Pertanian, Bandung: Pustaka Buana, 1985.

Sarwono hardjowigeno. Ilmu Tanah, Jakarta: Akademika Pressindo, 2003.

Siswadi. Budidaya Tanaman Palawija. Yogyakarta: PT Citra Aji Parama, 2006.

Siti Sutarmi Tjitrosomo, Botani Umum 2. Bandung: Angkasa, 2003.

Sri Pujiyanto. Biologi, Surakarta: PT Tiga Serangkai Pustaka Mandiri, 2004.

Subowo. Pemamfaatan Pupuk Hayati Cacing Tanah Untuk Meningkatkan Efisiensi Pengelolaan Tanah Pertanian Lahan Kering. Jurnal Pembangunan Manusia.

Sugiono. Metode Penelitian Kuantitatif, Kualitatif Dan $R$ \& D. Bandung : Alfabeta, 2007.

Suharsimi Arikonto. Prosedur Penelitian Suatu Pendekatan Praktik. Jakarta: Rineka Cipta, 2006.

Suhartono dkk. Pengaruh interval Pemberian Air Terhadap Pertumbuhan Dan Hasil Tanaman Kedelai (Glicine Max Merril) Pada berbagai Jenis Tanah. Jurnal Ilmiah, Embryo Vol. 5 No. I Juni 2008.

Suhirman dan Yahdi. Petunjuk Praktikum Pengetahuan Lingkungan. Mataram: IAIN Mataram, 2013.

Tim Penyusun. Kamus Bahasa Indonesia. Pusat Deprtement Pendidikan Nasional: Jakarta 2008.

Wahyu Qomara M, dan Asep Setiawan. Produksi Benih. Jakarta : Bumi Aksara, 2001.

Yuswar Yunus. Tanah dan Pengolahan. Jakarta: CV Alfabeta, 2004.

Zaenal Abidin, Dasar Pengetahuan Ilmu Tanaman. Bandung: Angkasa, 2004

244 ВIOTA: Jurnal Tadris IPA Biologi FITK IAIN Mataram 
Zainul Hamdi, dkk. Pengunaan Arang Hayati (Biochar) Sebagai Pencampur (Bulking Agent) Pada Proses Pengomposan Kotoran Sapi. Mataram: Program Studi Ilmu Tanah Fakultas Pertanian Universitas Unram, 2012. 